\title{
Inhibition of food-related bacteria by antibacterial substances produced by Pseudomonas sp. strains isolated from pasteurized milk
}

Inibição de bactérias associadas a alimentos por substâncias antimicrobianas produzidas por estirpes de Pseudomonas sp. isoladas de leite pasteurizado

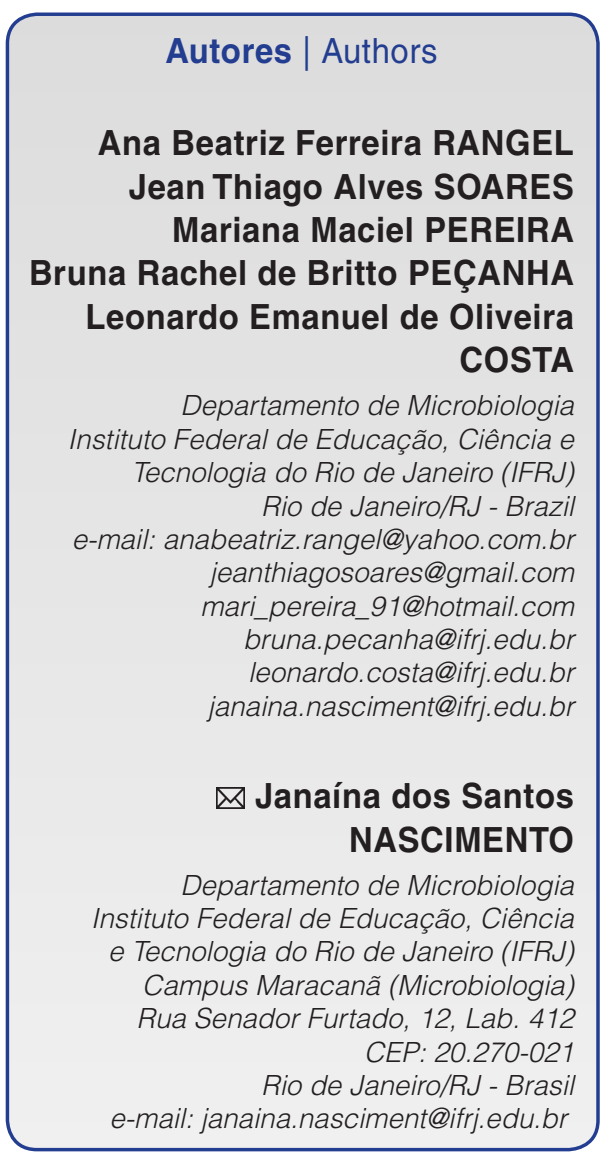

$\triangle$ Autor Correspondente / Corresponding Author

Recebido / Received: 08/29/2013 Aprovado / Approved: 11/01/2013 Publicado / Published: dez./2013

\section{Summary}

In this work, the production of antimicrobial substances by strains of Pseudomonas sp. isolated from pasteurized milk and their potential action against food-related bacteria were investigated. Samples of pasteurized milk were purchased from arbitrarily chosen commercial establishments in the city of Rio de Janeiro, Brazil. Of the four samples analyzed, three presented several typical colonies of Pseudomonas. About 100 colonies were chosen and subjected to biochemical tests for confirmation of their identity. Eighteen strains of the Pseudomonas genus were identified and submitted to tests for the production of antimicrobial substances. Twelve strains (66.7\%) were identified as Pseudomonas fluorescens, four (22.2\%) as P. aeruginosa, one (5.5\%) as P. mendocina and one (5.5\%) as P. pseudoalcaligenes. Only two P. fluorescens strains were unable to produce any antimicrobial substance against any of the indicator strains tested. Most of the strains presented a broad spectrum of action, inhibiting reference and food-related strains such as Proteus vulgaris, Proteus mirabilis, Hafnia alvei, Yersinia enterocolitica, Escherichia coli and Salmonella typhi. Five antimicrobial substance-producing strains, which presented the broadest spectrum of action, were also tested against Staphylococcus aureus reference strains and 26 Staphylococcus sp. strains isolated from foods, some of which were resistant to antibiotics. The producer strains 8.1 and 8.3 , both $P$. aeruginosa, were able to inhibit all the staphylococcal strains tested. The antimicrobial substances produced by strains 8.1 and 8.3 did not seem to be typical bacteriocins, since they were resistant to the three proteolytic enzymes tested. Experiments involving the characterization of these substances are being carried out in order to evaluate their biotechnological application.

Key words: Pseudomonas sp.; Antimicrobial substances; Milk; Foodborne pathogens; Staphylococcus spp. 


\section{Resumo}

Neste trabalho, a produção de substâncias antimicrobianas por estirpes de Pseudomonas sp. isoladas de leite pasteurizado e seu potencial de ação contra bactérias associadas a alimentos foram investigados. As amostras de leite pasteurizado foram adquiridas em estabelecimentos comerciais, arbitrariamente escolhidos, da cidade do Rio de Janeiro-RJ, Brasil. Dentre as quatro amostras analisadas, três apresentaram várias colônias típicas de Pseudomonas. Cerca de cem colônias foram escolhidas e submetidas a testes bioquímicos para confirmação da identificação. Dezoito estirpes do gênero Pseudomonas foram identificadas e submetidas aos testes de produção de substâncias antimicrobianas. Doze estirpes (66,7\%) foram identificadas como Pseudomonas fluorescens; quatro $(22,2 \%)$ como $P$. aeruginosa; uma (5,5\%) como P. mendocina, e uma (5,5\%) como $P$. pseudoalcaligenes. Apenas duas estirpes de $P$. fluorescens não foram capazes de produzir qualquer substância antimicrobiana contra os microorganismos indicadores testados. A maioria das estirpes apresentou um amplo espectro de ação, inibindo estirpes de referência e associadas a alimentos, como Proteus vulgaris, Proteus mirabilis, Hafnia alvei, Yersinia enterocolitica, Escherichia coli e Salmonella Typhi. Cinco estirpes produtoras de substâncias antimicrobianas, que apresentaram o mais amplo espectro de ação, também foram testadas contra estirpes de referência de Staphylococcus aureus e contra 26 estirpes de Staphylococcus sp. isoladas a partir de alimentos, sendo, algumas delas, resistentes a antibióticos. As estirpes produtoras 8.1 e 8.3 , ambas $P$. aeruginosa, foram capazes de inibir todas as estirpes de Staphylococcus testadas. As substâncias antimicrobianas produzidas pelas estirpes 8.1 e 8.3 não parecem ser bacteriocinas típicas, uma vez que foram resistentes às três enzimas proteolíticas testadas. Experimentos envolvendo a caracterização destas substâncias estão sendo realizados, a fim de avaliar a sua aplicação biotecnológica.

Palavras-chave: Pseudomonas sp.; Substâncias antimicrobianas; Leite; Patógenos associados a alimentos; Staphylococcus spp. 


\section{Introduction}

Although designed to supply complete nutrition for growing calves, bovine milk also provides an appropriate growth medium for a variety of microorganisms. The abundance of carbohydrates, proteins and fats in association with the neutral $\mathrm{pH}$ allows for the development of a microbial community which may be highly variable (ALI and ABDELGADIR, 2011).

Amongst the main reasons causing milk contamination are the poor conditions of hygiene during milking, insufficient cleaning procedures of the utensils and equipments and also problems related to the storage and transport (SILVA et al., 2011).

A variety of microorganisms with human pathogenic potential, including Listeria monocytogenes, Salmonella spp., Staphylococcus aureus and Mycobacterium tuberculosis, can be found in raw milk (ARCURI et al., 2006). However the presence of psychrotolerant bacteria belonging to various genera are extremely important in relation to the shelf life of milk and its derivatives, since they may develop even during long periods of cooling. During the storage of raw milk, these microorganisms can produce many proteolytic and lipolytic enzymes responsible for the spoilage of milk and dairy products, reducing both the quality and shelf life of the processed milk and resulting in important economic losses (FRANZETTI and SCARPELLINI, 2007; DE JONGHE et al., 2011).

Although the pseudomonas are also psychrotolerant microorganisms and are generally isolated from milk, they can also produce antimicrobial substances (AMS) able to inhibit other bacteria. Some Pseudomonas aeruginosa strains, for example, produce AMS called pyocins (MICHEL-BRIAND and BAYSSE, 2002; ELFARASH et al., 2012).

Since therapeutic antibiotics are prohibited for use in foods, the interest in these natural antimicrobial substances is increasing exponentially. Additives with antagonistic properties have become a trademark in the search for food safety and preservation. In food and drinks, the addition of antimicrobial compounds to processed products has become a powerful weapon in the arsenal of food preservation. These compounds, especially the bacteriocins, can be interesting strategies against the growth of undesirable microorganism (RILEY and WERTZ, 2002; ELFARASH et al., 2012, NISHIE et al., 2012).

Given the relevance of the research on antagonistic additives, this work aimed to characterize strains of Pseudomonas sp. isolated from pasteurized milk, and investigate the production of antimicrobial substances and their potential for action against the Gram-negative bacteria and staphylococci strains associated with food.

\section{Material and Methods}

\subsection{Milk samples and strains}

Four samples of pasteurized milk were purchased in arbitrarily chosen commercial establishments in the city of Rio de Janeiro, Brazil, and immediately taken for analysis. The staphylococcal strains presented in Table 1 were isolated in a previous study carried out by our research group. The other strains belong to the collection of the Laboratory of Microbiology of the Federal Institute of Rio de Janeiro, Brazil. All the strains used as indicators in this work were cultivated on Casoy agar (Himedia, Brazil) at $36{ }^{\circ} \mathrm{C}$ for 18 hours and stock cultures maintained in Casoy broth at $-20{ }^{\circ} \mathrm{C}$ with the addition of $40 \%$ glycerol.

\subsection{Isolation and identification of the bacteria}

The bacteria were isolated and identified according to Dworkin et al. (2006) and Franzetti and Scarpellini (2007). When necessary, bacterial identification was also carried out using the Bactray ${ }^{\circledR}$ commercial kit for bacterial identification (Laborclin, São Paulo, Brazil).

\subsection{Antibiotic resistance profile}

The antibiotic resistance profile of the strains isolated in this work was determined by disc diffusion in Mueller-Hinton agar according to the CLSI procedures (CLSI, 2012). The following antibiotics (Sensifar, São Paulo, Brazil) were used: aztreonam $(30 \mu \mathrm{g})$, cefotaxime $(30 \mu \mathrm{g})$, cefoxitin $(30 \mu \mathrm{g})$, ciprofloxacin $(5 \mu \mathrm{g})$, gentamicin $(10 \mu \mathrm{g})$, imipenem $(10 \mu \mathrm{g})$ and tetracycline $(30 \mu \mathrm{g})$.

\subsection{Production of antimicrobial substances and determination of the action spectrum}

This experiment was carried out as described by Giambiagi-Demarval et al. (1990). The pseudomonas bacteria isolated from milk were grown in $5 \mathrm{~mL}$ of Casoy broth (Himedia, Brazil) at $36{ }^{\circ} \mathrm{C}$ for $18 \mathrm{~h}$. Five microlitres of each culture were spotted onto Casoy plates. After $18 \mathrm{~h}$ at $37^{\circ} \mathrm{C}$, the bacteria were killed by chloroform fumes and the plates sprayed with the indicator strain culture $(0.3 \mathrm{~mL}$ of a previously grown culture in $3 \mathrm{~mL}$ of Casoy soft agar). The plates were incubated for a further $18 \mathrm{~h}$ at $37^{\circ} \mathrm{C}$ and the diameters of the inhibition zones measured (in $\mathrm{mm}$ ). Different Gram-negative and Gram-positive bacteria were used as the indicator strains for the production of antimicrobial substances.

\subsection{Susceptibility of the inhibitory substances to proteolytic enzymes}

The effect of the proteolytic enzymes trypsin (Sigma-Aldrich, São Paulo, Brazil), pronase XXIII (Sigma-Aldrich, São Paulo, Brazil) and proteinase K 
Inhibition of food-related bacteria by antibacterial substances produced by Pseudomonas sp. strains isolated from pasteurized milk

RANGEL, A. B. F. et al.

Table 1. Inhibition of staphylococcal strains isolated from food by the Pseudomonas producer strains 8.1 and 8.3.

\begin{tabular}{|c|c|c|c|c|}
\hline \multirow{2}{*}{$\begin{array}{l}\text { Indicator } \\
\text { strains }\end{array}$} & \multirow{2}{*}{ Identification } & \multirow{2}{*}{$\begin{array}{c}\text { Antibiotic } \\
\text { resistance profile }\end{array}$} & \multicolumn{2}{|c|}{ Inhibition by the producer strains } \\
\hline & & & 8.1 & 8.3 \\
\hline S4 & S. equorum & - & +++ & +++ \\
\hline S5 & S. equorum & - & ++ & ++ \\
\hline S10 & S. epidermidis & - & ++++ & +++ \\
\hline S11 & S. epidermidis & Amp, Pen & + & + \\
\hline S12 & S. epidermidis & Amp, Pen & + & + \\
\hline S14 & S. epidermidis & Tet & + & + \\
\hline S15 & S. epidermidis & Amp, Pen & + & + \\
\hline S16 & S. epidermidis & Pen & + & + \\
\hline S17 & S. lentus & Eri & + & + \\
\hline S18 & S. epidermidis & - & +++ & +++ \\
\hline S19 & S. epidermidis & - & + & + \\
\hline S23 & Staphylococcus sp. & Amp, Eri, Pen & + & + \\
\hline S24 & S. epidermidis & - & + & + \\
\hline S25 & S. carnosus & - & + & + \\
\hline S26 & S. equorum & Amp, Eri, Pen & + & + \\
\hline S29 & S.epidermidis & - & + & + \\
\hline S31 & Staphylococcus sp. & - & + & + \\
\hline S32 & Staphylococcus sp. & - & + & + \\
\hline S33 & Staphylococcus sp. & - & + & + \\
\hline S34 & Staphylococcus sp. & - & + & + \\
\hline S35 & S. hominis & - & + & + \\
\hline S36 & Staphylococcus sp. & - & ++ & ++ \\
\hline S37 & S. epidermidis & - & + & + \\
\hline S38 & Staphylococcus sp. & Ami, Amp, Ctx, Eri, Gen, Pen & +++ & +++ \\
\hline S39 & Staphylococcus sp. & Ctx & +++ & ++ \\
\hline S40 & S. hominis & - & +++ & +++ \\
\hline
\end{tabular}

+ , diameter of inhibition zones $\leq 20 \mathrm{~mm} ;++$, diameter of inhibition zones between 21 and $30 \mathrm{~mm} ;+++$, diameter of inhibition zones between 31 and $40 \mathrm{~mm}$; ++++, diameter of inhibition zones > 40 mm; -, no inhibition; Ami, amicacin; Amp, ampicillin; Ctx, cefotaxime; Eri, erythromycin; Pen, penicillin; Tet, tetracycline.

(Sigma-Aldrich, São Paulo, Brazil) on the antimicrobial substance activity was determined according to Giambiagi-Demarval et al. (1990). Forty microlitres of the enzymes ( $1 \mathrm{mg} / \mathrm{mL}$, prepared in $0.05 \mathrm{M}$ Tris ( $\mathrm{pH} 8.0$ ) with $0.01 \mathrm{M} \mathrm{CaCl}_{2}$ ) were applied around the producer strain after chloroform treatment. The plates were incubated at $37^{\circ} \mathrm{C}$ for $4 \mathrm{~h}$ and then sprayed with the indicator strain. After treatment with the enzymes, the absence of inhibition zones indicates that the antimicrobial substance presents an active proteinaceous compound.

\subsection{Susceptibility of the inhibitory substances to $\mathrm{NaOH}$}

The antimicrobial substances were also treated with $0.2 \mathrm{M} \mathrm{NaOH}$ to rule out the possibility that the inhibition exhibited could have been due to the production of organic acids by the producer strain during its metabolism. This assay was carried out according to Giambiagi-Demarval et al. (1990).

\section{Results and Discussion}

Of the four pasteurized milk samples analyzed, three presented several typical colonies suggestive of Pseudomonas sp.. About 100 colonies were arbitrarily chosen and subjected to biochemical tests for confirmation of their identity.

Of the eighteen strains analyzed belonging to the Pseudomonas genus, twelve (66.7\%) were identified as P. fluorescens, four (22.2\%) as P. aeruginosa, one (5.5\%) as $P$. mendocina and one $(5.5 \%)$ as $P$. pseudoalcaligenes (Table 2). The significant presence of $P$. fluorescens was expected, since other studies have also reported this species as the dominant spoilage species in refrigerated raw and pasteurized milk (DOGAN and BOOR, 2003; MUNSCH-ALATOSSAVA and ALATOSSAVA, 2006; 2007).

All the 18 strains selected were tested for resistance to different classes of antimicrobials. Five strains were only resistant to aztreonam, another only to cefotaxime and four to aztreonam and cefotaxime (Table 2). According to the 
Inhibition of food-related bacteria by antibacterial substances produced by Pseudomonas sp. strains isolated from pasteurized milk

RANGEL, A. B. F. et al.

literature, resistance to antibiotics has become common amongst strains isolated from milk and dairy products (ARSLAN et al., 2011; BEENA et al., 2011). Straley et al. (2006) verified that Pseudomonas spp. isolated from bulk tank milk samples were the dominant non-coliform Gram-negative bacteria and showed the highest levels of resistance to antibiotics. In a recent study, Arslan et al. (2011) verified that all 32 Pseudomonas strains isolated from cheese were susceptible to ciprofloxacin, gentamicin and imipenem. Antibiotic-resistant Pseudomonas spp. have significant importance in the dairy industries, since they are able to grow at low temperatures and have the potential to form biofilms (MARCHAND et al., 2012).

Table 2. Description of the Pseudomonas spp. strains isolated from milk.

\begin{tabular}{|c|c|c|c|}
\hline $\begin{array}{l}\text { Producer } \\
\text { strains }\end{array}$ & $\begin{array}{c}\text { Mik } \\
\text { sample }\end{array}$ & Identification & Characteristics \\
\hline 8.1 & 1 & $P$. aeruginosa & $\mathrm{AMS}^{+}$ \\
\hline 8.2 & 1 & P. aeruginosa & $\mathrm{AMS}^{+}$ \\
\hline 8.3 & 1 & P. aeruginosa & $\mathrm{AMS}^{+}$ \\
\hline E2A & 2 & P. fluorescens & $\mathrm{AMS}^{+}$ \\
\hline E2B & 2 & P. fluorescens & $\mathrm{AMS}^{+}$ \\
\hline E2C & 2 & P. fluorescens & $\mathrm{AMS}^{+}$ \\
\hline E2D & 2 & P. fluorescens & $\mathrm{CFT}^{\mathrm{R}}$ \\
\hline E2E & 2 & P. pseudoalcaligenes & $\mathrm{AMS}^{+}, \mathrm{AZT}^{\mathrm{R}}, \mathrm{CFT}^{\mathrm{R}}$ \\
\hline $\mathrm{CC} 2 \mathrm{G}$ & 2 & P. fluorescens & $\mathrm{AMS}^{+}, \mathrm{AZT}^{\mathrm{R}}, \mathrm{CFT}^{\mathrm{R}}$ \\
\hline $\mathrm{CC} 2 \mathrm{H}$ & 2 & P. fluorescens & $\mathrm{AMS}^{+}, \mathrm{AZT}^{\mathrm{R}}$ \\
\hline CC2I & 2 & P. fluorescens & $\mathrm{AMS}^{+}, \mathrm{AZT}^{\mathrm{R}}$ \\
\hline CC2J & 2 & P. fluorescens & $\mathrm{AMS}^{+}, \mathrm{AZT}^{\mathrm{R}}, \mathrm{CFT}^{\mathrm{R}}$ \\
\hline CC2K & 2 & P. fluorescens & $\mathrm{AMS}^{+}, \mathrm{AZT}^{\mathrm{R}}$ \\
\hline CC2L & 2 & $P$. aeruginosa & $\mathrm{AMS}^{+}, \mathrm{AZT}^{\mathrm{R}}$ \\
\hline CC2M & 2 & P. fluorescens & $\mathrm{AMS}^{+}, \mathrm{AZT}^{\mathrm{R}}$ \\
\hline CC2N & 2 & P. mendocina & $\mathrm{AMS}^{+}$ \\
\hline CC2O & 2 & P. fluorescens & $\mathrm{AMS}^{+}, \mathrm{AZT}^{\mathrm{R}}, \mathrm{CFT}^{\mathrm{R}}$ \\
\hline CC3P & 3 & P. fluorescens & $\mathrm{AMS}^{+}$ \\
\hline
\end{tabular}

$\mathrm{AMS}^{+}$, antimicrobial substance producer; $\mathrm{AZT}^{\mathrm{R}}$, resistant to aztreonam; $\mathrm{CFT}^{\mathrm{R}}$, resistant to cefotaxime.
The eighteen Pseudomonas sp. strains were also submitted to assays for the production of antimicrobial substances. All were able to produce antimicrobial substances against at least one of the indicator strains tested (Table 3). Differently from some of the antimicrobial substance-producer Pseudomonas, the antimicrobial spectrum of action of the strains isolated in this work was not restricted to pseudomonas (LAVERMICOCCA et al., 1999; RILEY and WERTZ, 2002).

In relation to Gram-negative indicator strains, $P$. aeruginosa 8.1, 8.2 and 8.3 presented the broadest spectrum of action and also the largest inhibition zones, inhibiting Proteus mirabilis, P. vulgaris, Hafnia alvei, Yersinia enterocolitica, Escherichia coli, Salmonella spp. Figure 1 shows some examples of the antimicrobial activity exhibited by strains 8.1 ad 8.3.

The inhibition of Salmonella sp. by Pseudomonas strains was also verified by Hubert et al. (1998). A Pseudomonas strain isolated from well water sediment produced the bacteriocin named PsVP-10, which showed a wide range of antibacterial action, inhibiting bacterial species such as S. typhi, S. typhimurium and S. sonnei, besides other microorganisms.

Interestingly, all the Gram-positive reference strains used as indicators were inhibited by $P$. aeruginosa 8.1 , 8.2 and also 8.3, including the three Staphylococcus reference strains (Table 3). So the inhibition ability of these three Pseudomonas producer strains against 26 strains of Staphylococcus spp. isolated from food in previous studies carried out by our research group was evaluated and the results are shown in Table 1. Some differences in the diameters of the inhibition zones were observed in this experiment, but all the staphylococcal strains were inhibited by these Pseudomonas strains. Strain 8.2 was not included in these tests, since its spectrum of action and the plasmidial DNA profile (data not shown) suggested that this strain was identical to strain 8.1.
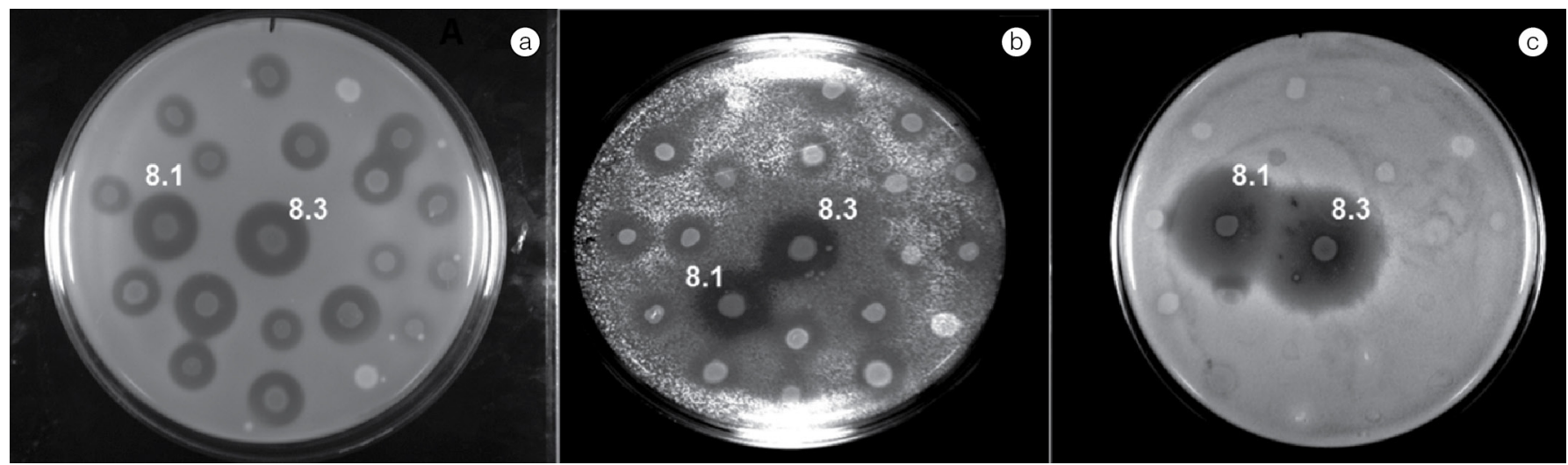

Figure 1. Agar-spot assay showing antimicrobial activity against (A) Proteus mirabilis, (B) Salmonella Typhi and (C) Staphylococcus aureus ATCC 12600. The inhibitory activity is represented by a clear zone around microbial inoculums (spots). Strains 8.1 and 8.3 are highlighted. 
Inhibition of food-related bacteria by antibacterial substances produced by Pseudomonas sp. strains isolated from pasteurized milk

RANGEL, A. B. F. et al.

Table 3. Inhibition of Gram-positive and Gram-negative bacteria by Pseudomonas spp. strains isolated from milk.

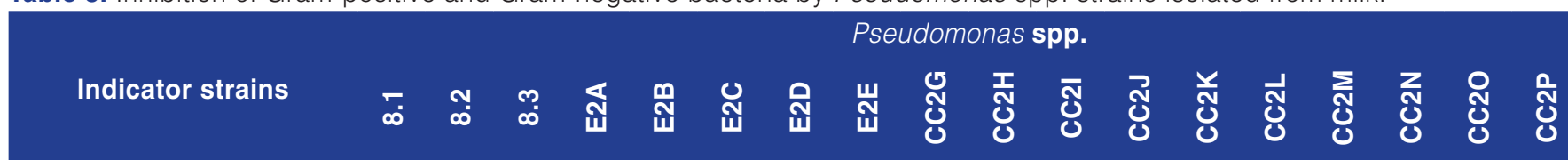

Gram-negative

Escherichia coli ATCC

25922

Hafnia alvei LMIFRJ

Klebsiella pneumoniae

ATCC 4352

Pseudomonas aeruginosa

ATCC27853

Pseudomonas fluorescens ATCC13525

Proteus mirabilis LMIFRJ

Proteus vulgaris LMIFRJ

Salmonella enterica Typhi ATCC 19214

Salmonella spp. I-LMIFRJ

Salmonella spp. VI-LMIFRJ

Yersinia enterocolitica

ATCC9610

Bacillus cereus LMIFRJ

Bacillus circulans LMIFRJ

Bacillus megaterium

LMIFRJ

Bacillus sphaericus

LMIFRJ

Bacillus

stearothermophilus

NCTC10339

Bacillus thuringiensis

LMIFRJ

Micrococcus luteus

LMIFRJ

Staphylococcus

epidermidis ATCC35984

Staphylococcus aureus

ATCC12600

Staphylococcus aureus

ATCC25923

Staphylococcus xylosus

LMIFRJ

Gram-positive

+ , inhibition (diameter of inhibition zones $\geq 20 \mathrm{~mm}$ ); -, no inhibition; \pm , small inhibition zones (diameter of inhibition zones $\leq 19 \mathrm{~mm}$ ); ATCC, American Type Culture Collection; LMIFRJ, Laboratory of Microbiology of Instituto Federal do Rio de Janeiro; NCTC, National Type Culture Collection.

A few studies have described the inhibition of Staphylococcus sp. by Pseudomonas, generally related to clinical strains. Qin et al. (2009) found that the extracellular products of $P$. aeruginosa PAO1, mainly polysaccharides, disrupted established S. epidermidis biofilms. Iwalokun et al. (2006) and Saleem et al. (2009) also showed that some pyocins obtained from Pseudomonas sp. associated with patients had antistaphylococcal activity. On the basis of the present results and those of the above mentioned studies, it appears that 
Inhibition of food-related bacteria by antibacterial substances produced by Pseudomonas sp. strains isolated from pasteurized milk

RANGEL, A. B. F. et al.

antimicrobial substances produced by Pseudomonas sp. could have the potential to be used not only in medical situations but also in the food industry.

To evaluate the presence of an active proteinaceous compound, the sensitivity of the antimicrobial substances to the proteolytic enzymes trypsin, proteinase $\mathrm{K}$ and pronase XXIII was verified. There was no loss of the inhibitory activity, indicating that the substances were resistant to these enzymes.

This fact suggests that they are not typical bacteriocins, although some bacteriocins produced by Pseudomonas sp. are not susceptible to proteolytic enzymes, such as the pyocin SA188 described by Naz and Rasool (2013). This substance is produced by $P$. aeruginosa and is not digested by proteases, proteinase $\mathrm{K}$, trypsin or papain. According to these authors, the findings are in agreement with the studies on pyocins, in which, of the three types of pyocin, $S, R$ and $F$, only the $S$ type is sensitive to proteolytic enzymes (NAZ and RASOOL, 2013).

The substances produced by strains 8.1 and 8.3 were also resistant to $\mathrm{NaOH}$, ruling out the possibility that the inhibition of the indicator was the result of acids released by the producer strains.

\section{Conclusions}

The consumer demand for food without the addition of chemical preservatives and the spread of antibioticresistant bacteria in food has driven the research for natural inhibitory substances. The results presented in this work highlight the antimicrobial activity of Pseudomonas spp. isolated from pasteurized milk against Gramnegative and Gram-positive food-related pathogens, such as Salmonella typhi and Staphylococccus sp., which play important roles in foodborne diseases around the world, even in developed countries. Since the inhibitory compounds produced by strains 8.1 and 8.3 could have a potential application in reducing the levels of pathogens in foods, further studies are being carried out, including the determination of the best conditions for the production of antimicrobial substances that have proved promising.

\section{Acknowledgements}

This work was supported by research grants from the Fundação de Amparo à Pesquisa do Estado do Rio de Janeiro (FAPERJ) and the Instituto Federal de Educação, Ciência e Tecnologia do Rio de Janeiro (IFRJ) and by J. S. Nascimento.

\section{References}

ALI, A. A.; ABDELGADIR, W. A. Incidence of Escherichia coli in Raw Cow's Milk in Khartoum State. British Journal of Dairy Sciences, Birminghan, v. 2, n. 1, p. 23-26, 2011.
ARCURI, E. F. Qualidade microbiológica do leite refrigerado nas fazendas. Arquivo Brasileiro de Medicina Veterinária e Zootecnia, Belo Horizonte, v. 58, n. 3, p. 440-446, 2006. http:// dx.doi.org/10.1590/S0102-09352006000300024

ARSLAN, S.; EYI, A.; OZDEMIR, F. Spoilage potentials and antimicrobial resistance of Pseudomonas spp. isolated from cheeses. Journal of Dairy Science, Champaign, v. 94, p. 12, p. 5851-5856, 2011.

BEENA, A. K.; RANJINI, A. R.; RIYA, T. G. Isolation of psychrotrophic multiple drug resistant Pseudomonas from pasteurized milk. Veterinary World, Rajkot, v. 4, n. 8, p. 349-352, 2011.

CLINICAL AND LABORATORY STANDARDS INSTITUTE - CLSI. Performance standards for antimicrobial susceptibility testing. Wayne: CLSI, 2012. Eighteenth informational supplement M100-S22.

DE JONGHE, V.; COOREVITS, A.; VAN HOORDE, K.; MESSENS, W.; VAN LANDSCHOOL, A.; DE VOS, P.; HEYNDRICKS, M. Influence of Storage Conditions on the Growth of Pseudomonas Species in Refrigerated Raw Milk. Applied and Environment Microbiology, Washington, v. 77, n. 2, p. 460-470, 2011. PMid:21115713 PMCid:PMC3020527. http://dx.doi.org/10.1128/ AEM.00521-10

DOGAN, B.; BOOR, K. J. Genetic diversity and spoilage potentials among Pseudomonas spp. isolated from fluid milk products and dairy processing plants. Applied and Environment Microbiology, Washington, v. 69, n. 1, p. 130-138, 2003. http://dx.doi.org/10.1128/AEM.69.1.130-138.2003

DWORKIN, M.; FALKOW, S.; ROSENBERG, E.; SCHLEIFER, K.-H.; STACKEBRANDT, E. (Eds.). The prokaryotes. 3rd ed. New York: Springer, 2006. v. 6.

ELFARASH, A.; WEI, Q.; CORNELIS, P. The soluble pyocins S2 and $S 4$ from Pseudomonas aeruginosa bind to the same FpvAl receptor. Microbiology Open, Brussel, v. 1, n. 3, p. 268-75, 2012. http://dx.doi.org/10.1002/mbo3.27

FRANZETTI, L.; SCARPELLINI, M. Characterisation of Pseudomonas spp. isolated from foods. Annals of Microbiology, Milan, v. 57, n. 1, p. 37-47, 2007.

GIAMBIAGI-DEMARVAL, M.; MAFRA, M. A.; PENIDO, E. G. C.; BASTOS, M. C. F. Distinct groups of plasmids correlated with bacteriocin production in Staphylococcus aureus. Journal of General Microbiology, London, v. 136, p. 1591-1599, 1990. http://dx.doi.org/10.1099/00221287-136-8-1591

HUBERT, E.; BREVIS, P.; LOBOS, O.; PADILLA, C. Purification and characterization of the bacteriocin PSVP-10 produced by Pseudomonas sp. Journal of Applied Microbiology, Bedford, v. 84, p. 910-913, 1998.

IWALOKUN, B. A.; AKINSINDE, K. A.; LANLENHIN, O.; ONUBOGU, C. C. Bacteriocinogenicity and production of pyocins from Pseudomonas species isolated in Lagos, Nigeria. 
Inhibition of food-related bacteria by antibacterial substances produced by Pseudomonas sp. strains isolated from pasteurized milk

RANGEL, A. B. F. et al.

African Journal of Biotechnology, Kenya, v. 5, n. 1, p. 10721077, 2006.

LAVERMICOCCA, P.; LONIGRO, S. L.; EVIDENTE, A.; ANDOLFI, A. Bacteriocin production by Pseudomonas syringae pv. ciccaronei NCPPB2355. Isolation and partial characterization of the antimicrobial compound. Journal of Applied Microbiology, Bedford, v. 86, n. 2, p. 257-265, 1999.

MARCHAND, S.; DE BLOCK, J.; DE JONGHE, V.; COOREVITS, A.; HEYNDRICKX, M.; HERMAN, L. Biofilm formation in milk production and processing environments; influence on milk quality and safety. Comprehensive Reviews in Food Science and Food Safety, Chicago, v. 11, p. 133-147, 2012. http://dx.doi. org/10.1111/j.1541-4337.2011.00183.x

MICHEL-BRIAND, Y.; BAYSSE, C. The pyocins of Pseudomonas aeruginosa. Biochimie, Paris, v. 84, p. 499-510, 2002. http:// dx.doi.org/10.1016/S0300-9084(02)01422-0

MUNSCH-ALATOSSAVA, P.; ALATOSSAVA, T. Phenotypic characterisation of raw milk-associated psychrotrophic bacteria. Microbiology Research, Pavia, v. 161, n. 4, p. 334-346, 2006. PMid:16459065. http://dx.doi.org/10.1016/j.micres.2005.12.004 MUNSCH-AlatossaVA, P.; AlatossaVA, T. Antibiotic resistance of raw-milk-associated psychrotrophic bacteria. Microbiology Research, Pavia, v. 162, n. 2, p. 115-123, 2007. PMid:16580186. http://dx.doi.org/10.1016/j.micres.2006.01.015

NAZ, S. A.; RASOOL, S. A. Isolation, production and characterization of bacteriocins produced by strains from indigenous environments. Pakistani Journal of Botanic, Karachi, v. 45, n. 1, p. 261-267, 2013.
NISHIE, M.; NAGAO, J.; SONOMOTO, K. Antibacterial peptides "bacteriocins": an overview of their diverse characteristics and applications. Biocontrol Science, Osaka, v. 17, n. 1, p. 1-16, 2012. http://dx.doi.org/10.4265/bio.17.1

QIN, Z.; YANG, L.; QU, D.; MOLIN, S.; TOLER-NIELSEN, T. Pseudomonas aeruginosa extracellular products inhibit staphylococcal growth, and disrupt established biofilms produced by Staphylococcus epidermidis. Microbiology, Reading, v. 155, n. 7, p. 2148-2156, 2009. PMid:19389780. http://dx.doi.org/10.1099/mic.0.028001-0

RILEY, M. A.; WERTZ, J. E. Bacteriocin diversity: ecological and evolutionary perspectives. Biochimie, Paris, v. 84, n. 5-6, p. 357-364, 2002. http://dx.doi.org/10.1016/S03009084(02)01421-9

SALEEM, F.; AHMAD, S.; YAQOOB, Z.; RASOOL, S. A. Comparative study of two bacteriocins produced by representative indigenous soil bacteria. Pakistani Journal of Pharmaceutical Sciences, Karachi, v. 22, n. 3, p. 252-258, 2009

SILVA, L. C. C.; BELOTI, V.; TAMANINI, R.; D'OVIDIO, L.; MATTOS, M. R.; ARRUDA, A. M. C. T.; PIRES, E. M. F. Semina: Ciências Agrárias, Londrina, v. 32, n. 1, p. 267-276, 2011.

STRALEY, B. A.; DONALDSON, S. C.; HEDGE, N. V.; SAWANT, A. A.; SRINIVASAN, V.; OLIVER, S. P.; JAYARAO, B. M. Public health significance of antimicrobial-resistant Gram-negative bacteria in raw bulk tank milk. Foodborne Pathogens and Disease, New Rochelle, v. 3, n. 3, p. 222-233, 2006. 